\title{
Carbon and nitrogen stable isotopic inventory of the most abundant demersal fish captured by benthic gears in southwestern Iceland (North Atlantic)
}

\author{
Gianluca Sarà • Maurizio De Pirro • Mario Sprovieri • \\ Paola Rumolo • Halldór Pálmar Halldórsson · \\ Jörundur Svavarsson
}

Received: 22 April 2008 / Revised: 13 April 2009 / Accepted: 16 April 2009 / Published online: 30 April 2009 (C) Springer-Verlag and AWI 2009

\begin{abstract}
Stable isotopes $\left(\delta^{13} \mathrm{C}\right.$ and $\left.\delta^{15} \mathrm{~N}\right)$ were used to examine the origin of organic matter for the most representative demersal species of the SW Icelandic fishery, accounting for over $70 \%$ of landings of those species in the North Atlantic. Samples were collected during a 2-week period in early September 2004 from landings and directly during fishing cruises. Stable isotopes showed that particulate organic matter and sedimentary organic matter were at the base of the food web and appeared to fill two different compartments: the pelagic and the benthic. The pelagic realm was composed of only capelin and sandeel; krill and redfish occupied an intermediate position between pelagic
\end{abstract}

Communicated by H.-D. Franke.

G. Sarà $(\bowtie)$

Dipartimento di Ecologia, Università di Palermo,

Via Scienze, Ed. 16, 90128 Palermo, Italy

e-mail: gsara@unipa.it

M. De Pirro

Dipartimento di Biologia Animale e Genetica,

Università degli Studi di Firenze, Via Romana 17,

50100 Florence, Italy

M. Sprovieri · P. Rumolo

IAMC-CNR, Calata Porta di Massa, Porto di Napoli,

80133 Naples, Italy

H. P. Halldórsson · J. Svavarsson

Suðurnes University Research Centre, University of Iceland,

Garðvegur 1, 245 Sandgerði, Iceland

H. P. Halldórsson · J. Svavarsson

Institute of Biology, University of Iceland, Askja,

Natural Science Building, Sturlugata 7, 101 Reykjavík, Iceland and benthic realms; while anglerfish, haddock, cod and ling resulted as the true demersal species while tusk, rays and plaice were strongly linked to the benthic habitat.

Keywords Demersal fish · Food web - Stable isotope · Iceland · North Atlantic

\section{Introduction}

The fishing industry in Iceland is one of the most important sectors of the country's economy. The Icelandic shelf, along with the western Canadian and Greenland banks and the eastern areas around Scandinavia and the British Isles, is among the most important fishing area of the North Atlantic (Arnason 1993). Nevertheless, despite the importance of Icelandic stocks and the high profile of its fishery, only scant information is available on the ecology of Icelandic demersal fish. This is surprising, as Icelandic stocks have long been thought to connect with other North Atlantic stocks, and further ecological insights gained into Icelandic stocks can also be valuable for the management of the entire North Atlantic fishing stocks. For example, the Greenland and Iceland cod stocks seem to be a mixed population and the dynamics of each are interdependent (Danielsson 1997; Jakobsson and Stefansson 1998). The demersal system includes the water column near to (and is significantly affected by) the seabed and the benthos. It is a multi-source environment where pelagic and benthic fluxes of organic matter combine, characterising a complex web composed of a large number of relationships among species, which are able to exploit different trophic and spatial niches. To date, studies investigating ecological features as trophic preferences and feeding habit of demersal species of Iceland system, e.g. cod, haddock, saithe and redfish, 
have been limited. For example, studies using stomach content analyses of demersal fish are only few (e.g. Bjornsson and Dombaxe 2004), while there is only one study using the stable isotope approach (Petursdottir et al. 2008), apart from several on birds which only marginally covered the isotopic composition of demersal species (Thompson et al. 1999). Knowledge of the identity and sources of prey consumed by fishes is, however, fundamental in understanding trophic relationships in most aquatic ecosystems. Insights into the trophic relationships and feeding habits of demersal species may be gained by using ratios of naturally occurring isotopes, often isotopes of carbon and nitrogen, in specific tissues (De Niro and Epstein 1978; 1981). Stable isotopes represent a valid tool in investigating the origin of organic matter assimilated by organisms (Sarà et al. 2007), and such an approach has helped ecologists to solve complicated dietary frames of organisms living in multi-trophic source environments (Michener and Schell 1994). In fact, the isotopic composition of organisms reflects that of the food available, apart from a certain degree of metabolic fractionation (i.e. feeder tissue is more positive than its food). The usual paradigm in isotopic dietary analysis is that metabolic fractionation follows a general scheme, producing an enrichment (i.e. values more positive) of the assimilated fraction for food; it is low or absent for carbon $(0-1.5 \%$ ) and more pronounced for nitrogen $(3.0-3.5 \%$ ) (Post 2002).

The present paper aims therefore, to represent the first isotopic inventory for a number of demersal fish around Iceland and structure by (1) listing the isotopic contents of the most important demersal species of Icelandic fishery and (2) identifying the main organic matter sources of the demersal system.

\section{Materials and methods}

Study site

The study area was the outer part of Faxaflói Bay (SW Iceland; $64^{\circ} 8^{\prime} \mathrm{N} ; 22^{\circ} 40^{\prime} \mathrm{W}$ ), which is a warm-boreal zone open to the Atlantic waters of the North Atlantic drift. Depth does not exceed $60 \mathrm{~m}$, salinity is about 35 , and the temperature is generally close to $2^{\circ} \mathrm{C}$ during the coldest months (January-March), rising to over $10^{\circ} \mathrm{C}$ at the south and west coasts during the summer. Physical and chemical features of the Icelandic waters are further described in Jakobsson and Stefansson (1998). The fishing industry of Iceland is the mainstay of the national economy and represents one of the most important in the North Atlantic (Danielsson 1997). The 2004 total catch in the Iceland grounds was about $1,700,000$ tons, which was higher than other fishing zones (Norwegian, Russian, Flemish Cap and other banks; data from http://www.statice.is/). The south-western and the capital region catches represented $15-20 \%$ of the total landings in Iceland in 2004.

\section{Data collection and analysis}

Samples were collected during a 2 -week period in early September 2004 from landings stored in the fish market of Sandgerdi (Iceland) and directly during fishing cruises on the fishing vessel 'Askur', operating south of the coasts of the Reykjanes Peninsula, using bottom trawl (Danish seine) at a mean depth of 25-30 m. From the fish market, we collected muscle samples from the most represented fishes, which were captured not more than 5-6 h before. During the fishing cruises, we collected, directly in the field muscle of fish. Thirteen fish species, plus the Norway lobster Nephrops norvegicus, were the targets in the present study, as they were the most representative catches in September in the study area. Sandeel (Ammodytes sp.; not commercially fished in Iceland) was obtained from the frozen collection kept in the Sandgerdi Marine Centre (BIOICE Project), while undigested krill (unidentified species; $>15 \mathrm{~mm}$ ) and capelin (Mallotus villosus; $\sim 50 \mathrm{~mm}$ ) were obtained from stomach contents directly on the vessel. Samples of subsurface seawater $(-5 \mathrm{~m})$ from the Reykjavik offshore area were collected during the cruises using a 4-1 Niskin bottle and a $60-\mu$ horizontal net collecting phytoplanktonic and microzooplanktonic organisms from subsurface $-5 /-7 \mathrm{~m}$ layers for at least $20 \mathrm{~min}$. The water collected from Niskin (hereafter called POM-w to indicate particulate organic matter collected with Niskin) and net (hereafter called POM-net to indicate particulate organic matter collected with $60-\mu$ horizontal net) was filtered in a few hours, using the Sandgerdi Marine Centre facilities, through pre-combusted $\left(450^{\circ} \mathrm{C}, 4 \mathrm{~h}\right)$ Whatman $\mathrm{GF} / \mathrm{F}$ filters for the isotopic analysis of the particulate organic matter (POM). Samples of sedimentary organic matter (SOM) were obtained from the top centimetre of sediment by hand using small corers (i.d. $=4 \mathrm{~cm})$ from near-shores $(\sim 4 \mathrm{~m}$ deep) in the areas of Sandgerdi (Osar Bay) and off Hvassahraun. Muscle tissue samples were dissected from fish, while invertebrates obtained from trawls or from fish stomachs were mainly analysed whole. Unfortunately, due to logistic limitations during cruises imposed by fishermen, stomach content analysis was not carried out. All samples (POM, $\mathrm{SOM}$, invertebrates and fish) were dried at $60^{\circ} \mathrm{C}$ for several hours (from 24 to $72 \mathrm{~h}$ as a function of the substrate analysed) and ground with a pestle and mortar (Abed-Navandi and Dworschak 2005). Only carbon samples were acidified. The isotopic analyses were performed using a Finnigan Delta-S isotope ratio mass spectrometer. Isotopic values were expressed in parts per thousand as deviations from standards (Peedee belemnite limestone for $\delta^{13} \mathrm{C}$ and 
nitrogen in air for $\left.\delta^{15} \mathrm{~N}\right): \delta^{13} \mathrm{C}$ or $\delta^{15} \mathrm{~N}=\left[\left(R_{\text {sample }} /\right.\right.$ $\left.\left.R_{\text {standard }}\right)-1\right] \times 10^{3}$, where $R={ }^{13} \mathrm{C} /{ }^{12} \mathrm{C}$ or ${ }^{15} \mathrm{~N} /{ }^{14} \mathrm{~N}$. Student's $t$ test was used to analyse possible differences between stable isotopic compositions of species (Sokal and Rohlf 1981).

\section{Results}

Isotopic characterisation of sources and invertebrates

In the present study, we collected the most representative demersal species of the SW Icelandic fishery, accounting for over 70\% of landings of those species in the North Atlantic (Table 1). We used two methods for collecting the $\mathrm{POM}$, aiming to individuate two different water column isotopic signals. The POM collected using a Niskin bottle (POM-w) was a mixed signal of sestonic organic matter; it was more negative in $\delta^{13} \mathrm{C}$ and $\delta^{15} \mathrm{~N}(-21.2$ and 5.2\%o, respectively) than POM-net which was composed by small planktonic organisms (mostly zooplankton; $\delta^{13} \mathrm{C}=-19.2 \%$ o and $\delta^{15} \mathrm{~N}=10.7 \%$, respectively). SOM from the near-shore in the Sandgerdi area showed values of $-17.2 \%$ regarding the $\delta^{13} \mathrm{C}$ and $5.8 \%$ of $\delta^{15} \mathrm{~N}$. Unidentified crustacean species collected directly from stomach contents of fish, referred to as krill in the present paper (mostly Euphausiids), and the lobsters collected from the net, were the most abundant invertebrates found in the study area in early September. Both had a carbon signal around $-17.0 \%$, the lobster slightly more enriched (Table 1), and they showed the same values of $\delta^{15} \mathrm{~N}(11.0 \%)$.

\section{$\delta^{13} \mathrm{C}$ and $\delta^{15} \mathrm{~N}$ in fish}

The carbon isotopic composition of all fish highlighted a group showing more negative values of $\delta^{13} \mathrm{C}$ (Table 1). M. villosus collected directly from fish stomach had lower $\delta^{13} \mathrm{C}$ values than the POM-water; the sandeel had very similar $\delta^{13} \mathrm{C}$ values to the POM-water, but these were slightly lower than the POM-net. The redfish was slightly more positive than the POM-net. Starting with the halibut, all fish had more positive carbon values, up to the plaice, which represented the end of this sequence, with $\delta^{13} \mathrm{C}$ values around $-15.0 \%$. Sandeel had the lowest $\delta^{15} \mathrm{~N}$ value $(9.0 \%$ ), while ${ }^{15} \mathrm{~N}$ increased with capelin, tusk and redfish, reaching the highest value $(16.0 \%$ ) in ling (Table 1). In Fig. 1 the scatter plot $\delta^{13} \mathrm{C}-\delta^{15} \mathrm{~N}$ shows the structure of food web in the Faxaflói system. POM-w and SOM were at the base of the food web, and appeared to fill two different compartments: the pelagic and the benthic. The pelagic part was very simple as composed of only capelin and sandeel. POM-net, which had isotopic values consistent with small zooplankton, was in the middle with redfish and krill. Anglerfish, haddock, cod and ling were clustered together at the

Table 1 Carbon $\left(\delta^{13} \mathrm{C}\right)$ and nitrogen $\left(\delta^{15} \mathrm{~N}\right)$ composition of all species included in the present study and total catch (www.statice.is) for the period 2003-2005

\begin{tabular}{|c|c|c|c|c|c|c|c|c|c|}
\hline Label & Type & Common name & $\begin{array}{l}\text { Total catch } \\
\text { (tons) }\end{array}$ & $\begin{array}{l}\text { Total catch for } \\
\text { each species }(\%)\end{array}$ & $\begin{array}{l}\text { Number of } \\
\text { individuals } \\
\text { analysed } n\end{array}$ & $\delta^{13} \mathrm{C}$ & SD & $\delta^{15} \mathrm{~N}$ & SD \\
\hline POM-w & Particulate OM (Niskin) & POM & - & & 3 & -21.1 & 0.4 & 5.2 & 0.5 \\
\hline POM-n & Particulate OM $(60-\mu$ net $)$ & POM & - & & 4 & -19.2 & 1.5 & 10.7 & 0.5 \\
\hline SOM & Sedimentary OM & $\mathrm{SOM}$ & - & & 3 & -17.4 & 0.4 & 5.8 & 0.2 \\
\hline Krill & Unidentified various sp. & Krill & - & & 10 & -17.9 & 0.2 & 11.0 & 0.3 \\
\hline Neph & Nephrops norvegicus & Lobster & 145.3 & 0.8 & 5 & -16.2 & 0.2 & 11.1 & 0.1 \\
\hline $\mathrm{Amm}$ & Ammodytes sp. & Sand Eel & - & - & 7 & -20.8 & 0.1 & 9.3 & 0.4 \\
\hline An-1 & Anarhichas lupus & Wolf-fish Catfish & 2041.3 & 1.2 & 8 & -16.5 & 0.6 & 13.1 & 1.7 \\
\hline B-b & Brosme brosme & Tusk & 2342.6 & 1.3 & 8 & -15.7 & 0.6 & 11.1 & 2.5 \\
\hline G-m & Gadus morhua & Cod & 43621.7 & 25.0 & 6 & -17.0 & 0.5 & 12.8 & 0.1 \\
\hline $\mathrm{H}-\mathrm{h}$ & Hippoglossus hippoglossus & Atlantic halibut & 93.3 & 0.5 & 4 & -17.5 & 0.3 & 12.4 & 0.1 \\
\hline L-p & Lophius piscatorius & Anglerfish & - & - & 5 & -16.7 & 0.3 & 14.3 & 0.2 \\
\hline$M-v$ & Mallotus villosus & Capelin & 54508.0 & 31.0 & 5 & -22.5 & 0.3 & 10.8 & 0.1 \\
\hline M-a & Melanogrammus aeglefinus & Haddock & 8018.7 & 4.5 & 4 & -16.6 & 0.3 & 13.6 & 0.7 \\
\hline M-m & Molva molva & Ling & 1985.0 & 1.1 & 5 & -16.6 & 0.1 & 16.2 & 0.1 \\
\hline P-p & Pleuronectes platessa & European plaice & 1482.3 & 0.8 & 6 & -15.6 & 0.7 & 12.0 & 0.7 \\
\hline $\mathrm{P}-\mathrm{v}$ & Pollachius virens & Saithe & 11166.6 & 8.2 & 4 & -16.7 & 0.2 & 12.6 & 0.3 \\
\hline R-r & Raja radiata & Starry ray & 479.0 & 0.3 & 3 & -15.9 & 0.1 & 11.7 & 0.1 \\
\hline S-m & Sebastes spp. & Redfish & 7975.3 & 4.5 & 5 & -18.6 & 0.1 & 11.6 & 0.1 \\
\hline
\end{tabular}




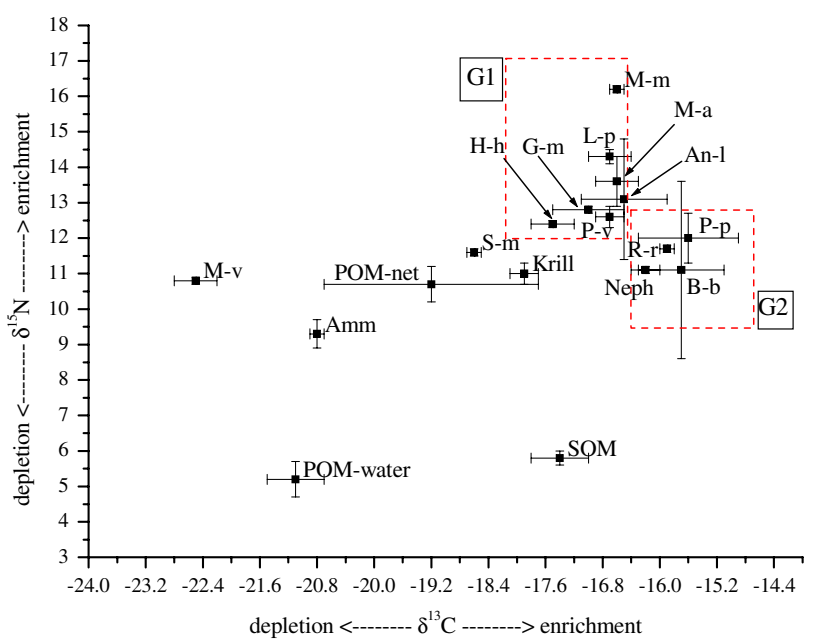

Fig. $1 \delta^{13} \mathrm{C}-\delta^{15} \mathrm{~N}$ scatter-plot of all species included in the present study (standard deviations are reported; for details on acronyms see Table 1). Two significantly different groups of species (G1 and G2) are highlighted in the figure (Student's $t$ test $P<0.05$ ). Other species like M-m, M-v, Amm, S-m, Krill, POM and SOM were significantly different from all (Student's $t$ test $P<0.05$ ) [Stable isotope ratios measure the ratio of the heavy $\left({ }^{13} \mathrm{C}\right.$ and $\left.{ }^{15} \mathrm{~N}\right)$ and light $\left({ }^{12} \mathrm{C}\right.$ and $\left.{ }^{14} \mathrm{~N}\right)$ in a sample. Thus, samples that contain more of the heavy isotope are referred to as "enriched" and are "heavier" than other samples (i.e. values tending to be more positive); those that contain less of the heavy isotope are "depleted" and are "lighter" than other samples (i.e. values tending to be more negative]

top of the web, while SOM appeared to fill the benthic part of food web, which was composed by tusk, rays and plaice.

\section{Discussion}

Lower trophic levels (POM, SOM, capelin and sandeel)

The SW Iceland demersal base line of organic matter was mainly of marine origin. Isotopic composition of POM collected from subsurface waters in early September fell within the pelagic range for different offshore areas of the North Atlantic, far from continental influences (Fry 1988; Lesage et al. 2001). Sedimentary organic matter had values falling well within the normal range of sediments of autochthonous marine origin, with some influence from the proximity of near-shore habitats (Takai et al. 2002). Values of $\delta^{13} \mathrm{C}$ around $-17.0 \%$ and $\delta^{15} \mathrm{~N}$ around $6.0 \%$, as measured in the present study, suggested an influence of algal mixed detritus that is probably shifted from near to offshore by the internal Faxaflói Bay circulation. The dominant algae along the SW coasts of Iceland are represented by Fucus spp. and Ascophyllum nodosum, whose carbon and nitrogen isotopic values were around those of the present study (Lesage et al. 2001; Sarà et al. 2007). Thus, SOM had isotopic values showing a mixed influence of near and offshore, without or with a very negligible trace of terrestrial (sensu Sherwood and Rose 2005) and pelagic contributions (Takai et al. 2002). We also collected water with a $60-\mu$ net at $5-7 \mathrm{~m}$ below the surface. According to our visual observations, POM-net was mostly composed of unidentified zooplankton. Its isotopic composition was different from the POM-w (see Frazer 1996), providing a good measure of a planktonic fraction, mostly composed of animals. The $\delta^{13} \mathrm{C}$ and $\delta^{15} \mathrm{~N}$ values indicated the small zooplanktonic origin of this mixture, likely grazed on those organisms found within POM-w samples (mostly phytoplankton). This was also supported by differences in the carbon isotope between POM-w and POM-n (i.e. indicating a metabolic fractionation of around 1.0-1.5\%; Post 2002).

Krill (mostly Euphausiids of about $15-20 \mathrm{~mm}$ found in the stomach contents of some specimens of demersal fish, mainly cod) showed an isotopic composition reflecting the direct grazing on zooplankton (Petursdottir et al. 2008). Krill displayed slightly enriched values of carbon and nitrogen with respect to Euphausiids of Labrador (Sherwood and Rose 2005) and Antarctica (Frazer 1996) and those collected in late spring in the same area by Petursdottir et al. (2008), similar nitrogen content to Californian krill (Sydeman et al. 1997) but lower compared to Pacific Japanese krill (Mitani et al. 2006). The disparities in $\delta^{15} \mathrm{~N}$ values may reflect the difference in latitude at which they were feeding and seasonality (sensu Frazer 1996).

Sandeel composition (below POM-w) indicated an isotopic depletion (i.e. more negative value) with respect to POM-w. This is unusual as consumers should be graphically located above their potential food. Nevertheless, this could be explained by the fact that Ammodytes sp. samples were not collected simultaneously with the other organisms (early September), resulting in a slightly shifted isotopic composition, presumably attributable to seasonality. Our results are consistent with other isotopic findings both from Iceland (Thompson et al. 1999) and other areas (Fry 1988; Thompson and Furness 1995; Bearhop et al. 1999; Estrada et al. 2003; Møller 2006), although nitrogen was depleted with respect to values reported elsewhere (Jenning et al. 2001). The isotopic frame of the sandeel is consistent with the foraging behaviour described previously (Robards et al. 1999); it is a small inshore semi-demersal fish, mainly relying on small zooplankton and large diatoms.

Like sandeel, capelin is planktivorous transferring energy up the food web to larger piscivorous, including fish, seals, whales and birds (Lawson and Stenson 1997; Montevecchi 2001; Hanson and Chouinard 2002; Kurle 2002; Davoren et al. 2006). Capelin is a short-lived, pelagic schooling species, important prey for many demersal fish in northern oceans, sustaining most of their stocks. More negative values (about a couple of per mill) than other isotopic findings (Thompson et al. 1999; Kurle 2002; Sherwood and Rose 2005) would suggest a partial terrestrial contribution to its assimilated 
fraction likely explained by the fact that capelin can also exploit freshwater areas, both for refuge and spawning (Vesin et al. 1981; Savenkoff et al. 2004). Nitrogen values were, however, coincident with other results reported for capelin (Thompson et al. 1999).

\section{The G1 group: true demersal organisms}

Cod, haddock, saithe, redfish, halibut and anglerfish were the most represented species in the Icelandic catch (Jakobsson and Stefansson 1998; Livingston and Tjelmeland 2000; www.statice.is). They were closely related amongst each other (Hoines and Bergstad 1999) and their $\delta^{15} \mathrm{~N}$ values seem to support the notion that they likely derived their nitrogen from capelin and sandeel. Indeed, they fell within the normal fractionation range in the literature for the reliance of a species on another (3-5\%o; De Niro and Epstein 1978; 1981; Minagawa and Wada 1984; Post 2002). In contrast, our data did not fit with regard to carbon since both capelin and sandeel were too depleted (i.e. negative) to justify a preferential exploitation of them by demersal fish. The carbon depletion of capelin is particularly evident (Fig. 1), and that contrasted a little with assumption in the literature of capelin as the main prey for demersal species (see above), although they were directly collected from fish stomachs.

The redfish (Sebastes spp.) seems the only species mainly relying on POM-net and krill from which it derives both carbon and nitrogen. This supports the redfish rely preferentially on zooplankton (Palsson 1985; Pedersen and Riget 1993; Husebø et al. 2002) and larger krill which is consistent with other isotopic findings (Magnusson and Magnusson 1995; Thompson et al. 1999; Jenning et al. 2001; Møller 2006; Petursdottir et al. 2008).

The Atlantic halibut is classified as a pure demersal species and is mainly benthic-nekton feeder (Haug 1990; www.fishbase.org). Its isotopic composition was compatible with bottom-related prey preferences and relied on redfish, sandeel and capelin. Our isotopic findings appear to be the only ones regarding $H$. hippoglossus; other organisms occupying a similar habitat in other geographical areas (e.g. Hippoglossoides platessoides) seem to have similar isotopic compositions justifying both habitat and preferred diet, as revealed by our isotopic study (Fry 1988; Pedersen and Riget 1993; Jenning et al. 2001; Møller 2006).

Saithe had similar isotopic composition to halibut. Saithe is classified as a pure gregarious demersal fish relying mainly on other fish (e.g. sandeel, Hall et al. 1990; small haddock, Du Buit 1991), but also on benthic organisms among which lobsters seem to represent a main item (Hanson and Lanteigne 2000). Thus, isotopic composition of Icelandic saithe reflected a diet based on fish (sandeel and capelin but also large zooplankton) and with a certain influence of benthic organic matter (see Hoines and Bergs$\operatorname{tad}$ 1999).

Cod is the most important species in most fishery industries of the North Atlantic, and literature on its stocks dynamics is vast. Our data are consistent with most isotopic findings to date (Fry 1988; Thompson et al. 1999; Møller 2006) but more depleted with respect to Celtic cods (Jenning et al. 2001). The position in the demersal food web could be compatible with its pure demersal behaviour feeding in all areas, from the surface (Lilly 1987) to the bottom (Bjornsson 2002), with an omnivorous regime (see www.fishbase.org).

Together with cod and saithe, haddock represents the other main source for fisheries of the North Atlantic and fed both on the bottom (various benthic organisms; Hoines et al. 1992; Hoines and Bergstad 1999) and in the water column (Jiang and Jørgensen 1996). Despite its commercial and ecological importance, very few isotopic data are available on this species. Our data were more or less coincident with other isotopic findings (Fry 1988; Jenning et al. 2001; Møller 2006) justifying diet preferences highlighted in the present study.

\section{The G2 group: true benthic organisms}

Anglerfish collected in Iceland had an isotopic composition similar to L. americanus of Georges Bank (Fry 1988) compatible with its benthic role of top piscivore species relying on other demersal fishes (Crozier 1985). Also the wolffish, A. lupus, showed an isotopic composition, indicating a fish-based diet, coincident with data reported for west Greenland (Møller 2006) and the North Sea (Jenning et al. 2001). In this study, the species with the highest nitrogen values was the ling. Our isotopic findings agree and previously described diet preferences supported M. molva as preying almost exclusively on larger demersal species (i.e. cod, haddock, saithe, wolffish) and benthic fish (mostly plaice), but benthic invertebrates are also among its preferences. Due to logistic limitations, we were not able to collect other important benthic species potentially entering the diet of organisms considered in this study; thus the only species considered was lobster, although urchins, mussels and other smaller invertebrates usually are considered ling's preys (Hagen and Mann 1992; Le Loc'h and Hily 2005). This fits well with the image of lobster as the top mobile predator in the benthic habitat. If we compare its nitrogen content $(>11 \%$ o), for example, with that of other invertebrates from other geographical areas (but at the same latitude, e.g. Georges Bank; Fry 1988), we can envisage a clear role of carnivorous preying on several low-level invertebrates. Lobsters were among the preferred prey of tusks, rays and plaice (see www. fishbase.org). 
Tusks represent an important species of the benthic habitat, but there is a surprising lack of information on it (see www.fishbase.org). Its diet has only been described a few times, and it appears to be based on benthic fish and invertebrates (Bowman et al. 2000). Our isotopic findings reflect the frame obtained with the stomach content analysis. Its isotopic composition is compatible with a benthic-based diet. The only comparable isotopic finding for tusk is reported in Jenning et al. (2001) which showed more enriched nitrogen values compared to the present study (14.3 vs. $11.1 \%$ ).

Rays are considered top benthic feeders everywhere in the world, and isotopic analysis showed rays were affected by benthic invertebrates and smaller fish (Berestovskiy 1990; Daan et al. 1993; Morato et al. 2003). A co-generic species in the Celtic Sea was more enriched in ${ }^{15} \mathrm{~N}$ (Jenning et al. 2001), while ray values from Georges Bank were coincident with our values for both carbon and nitrogen (Fry 1988).

Adults of European plaice consume mainly benthic invertebrates and occasionally nekton. This is supported by present isotopic analysis, and the higher enrichment in ${ }^{15} \mathrm{~N}$ (i.e. more positive nitrogen values) corroborated the idea that plaice would rely upon benthic carnivorous species (e.g. polychaetes) as the flounders on the Flemish Cap (the diet was mainly composed of polychaetes; $80 \%$ volume; Rodriguez-Marin et al. 1994) and from the St. Lawrence Gulf (Morisette 2001). European plaice captured in Iceland had similar compositions to P. americanus from Georges Bank (Fry 1988) and flounders from Japanese coasts (Yamaguchi et al. 2006), while our data were always lower in nitrogen with respect to flounder and plaice of the North and Celtic Seas (Jenning et al. 2001).

Acknowledgments Authors are very grateful to Mr. Guðmundur Víðir Helgason for arrangements, help and hospitality during their stay at the Sandgerdi Marine Centre (SMC), Iceland, and for making available the invertebrate collections from the international BIOICE project (Benthic Invertebrates of Icelandic waters). Thanks are also to the director of the Nature Centre Mr. Reynir Sveinsson, the director of the Sandgerdi fish market (Fiskmarkaður Suðurnesja), Mr. Ragnar Kristjánsson, the crew of fishing the vessel 'Askur' and all the staff at the SMC for their kindness and help. The stay at the SMC was supported by the programme "Improving Human Potential: Access to Research Infrastructure"' (IHP/ARI) provided by the European Community.

\section{References}

Abed-Navandi D, Dworschak PC (2005) Food source of tropical Thalassinidean shrimps: a stable isotope study. Mar Ecol Progr Ser 291:159-168

Arnason R (1993) The Icelandic individual transferable quota system: a descriptive account. Mar Resour Econ 8:201-218

Bearhop S, Thompson DR, Waldron S, Russel IC, Alexander G, Furness RW (1999) Stable isotopes indicate the extent of freshwater feeding by cormorants Phalacrocorax carbo shot at inland fisheries in England. J Appl Ecol 36:75-84

Berestovskiy EG (1990) Feeding in the skates, Raja radiata and Raja fyllae, in the Barents and Norwegian Seas. J Appl Ichth 29:88-96

Bjornsson B (2002) Effects of anthropogenic feeding on the growth rate, nutritional status and migratory behaviour of free-ranging cod in an Icelandic fjord. ICES J Mar Sci 59:1248-1255

Bjornsson B, Dombaxe MAD (2004) Quality of Nephrops as food for Atlantic cod (Gadus morhua L) with possible implications for fisheries management. ICES J Mar Sci 61:983-991

Bowman RE, Stillwell CE, Michaels WL, Grosslein MD (2000) Food of northwest Atlantic fishes and two common species of squid. NOAA Tech Mem NMFS-NE 155:138

Cabana G, Rasmussen JB (1996) Comparison of aquatic food chains using nitrogen isotopes. Proc Nat Acad Sci (USA) 93:1084410847

Crozier WW (1985) Observations on the food and feeding of the angler-fish, Lophius piscatorius L., in the northern Irish Sea. J Fish Biol 27:655-665

Daan N, Johnson B, Larsen JR, Sparholt H (1993) Analysis of the ray (Raja spec) samples collected during the 1991. Int Stomach Sampl Project ICES CM 1993/G 15: 17

Danielsson A (1997) Fisheries management in Iceland. Ocean Coast Manage 35:121-135

Davoren GK, Anderson JT, Montevecchi WA (2006) Shoal behaviour and maturity relations of spawning capelin (Mallotus villosus) off Newfoundland: demersal spawning and diel vertical movements. Can J Fish Aq Sci 63:268-284

De Niro MJ, Epstein S (1978) Influence of diet on the distribution of carbon isotopes in animals. Geochim Cosmochim Acta 42:495506

De Niro MJ, Epstein S (1981) Influence of diet on the distribution of nitrogen isotopes in animals. Geochim Cosmochim Acta 45:341351

Du Buit MH (1991) Food and feeding of saithe (Pollachius virens L) off Scotland. Fish Res 12:307-323

Estrada JA, Rice AN, Lutcavage ME, Skomal GB (2003) Predicting trophic position in sharks of the North-west Atlantic Ocean using stable isotope analysis. J Mar Biol Ass UK 83:1347-1350

Frazer TK (1996) Stable isotope composition $\left(\delta^{13} \mathrm{C}\right.$ and $\left.\delta^{15} \mathrm{~N}\right)$ of larval krill, Euphausia superba, and two of its potential food sources in winter. J Plank Res 18:1413-1426

Fry B (1988) Food web structure on Georges Bank from stable C, N, and S isotopic compositions. Limnol Oceanogr 33:1182-1190

Hagen NT, Mann KH (1992) Functional response of the predators American lobster Homarus americanus Milne-Edwards and Atlantic wolf fish Anarhichas lupus L. to increasing numbers of the green sea urchin Strongylocentrotus droebachiensis Mueller. J Exp Mar Biol Ecol 159:89-112

Hall SJ, Raffaelli D, Basford DJ, Robertson MR, Fryer R (1990) The feeding relationships of the larger fish species in a Scottish Sea Loch. J Fish Biol 37:775-791

Hanson JM, Chouinard GA (2002) Diet of Atlantic cod in the southern Gulf of St Lawrence as an index of ecosystem change, 19592000. J Fish Biol 60:902-922

Hanson JM, Lanteigne M (2000) Evaluation of atlantic cod predation on American lobster in the southern Gulf of St Lawrence, with comments on other potential fish predators. Trans Am Fish Soc 129:13-29

Haug T (1990) Biology of the Atlantic halibut, Hippoglossus hippoglossus (L. 1758). Adv Mar Biol 26:26-35

Hoines A, Bergstad OA (1999) Resource sharing among cod, haddock, saithe and pollack on a herring spawning ground. J Fish Biol 55:1233-1257

Hoines A, Bergstad OA, Albert OT (1992) Seasonal variation of the diet of cod (Gadus morhua L) and haddock (Melanogrammus 
aeglefinus $\mathrm{L}$ ) at a herring spawning ground. ICES J Mar Sci 9:123

Husebø Å, Nøttestad L, Fosså JH, Furevik DM, Jørgensen SB (2002) Distribution and abundance of fish in deep sea coral habitats. Hydrobiologia 471:91-99

Jakobsson J, Stefansson G (1998) Rational harvesting of the cod-capelin-shrimp complex in the Icelandic marine ecosystem. Fish Res 37:7-21

Jenning S, Pinnegar JK, Polunin NVC, Boon TW (2001) Weak crossspecies relationships between body size and trophic level belie powerful size-based trophic structuring fish communities. J Anim Ecol 70:934-944

Jiang W, Jørgensen T (1996) The diet of haddock (Melanogrammus aegelfinus L.) in the Barents Sea during the period 1984-1991. ICES J Mar Sci 53:11-21

Kurle KM (2002) Stable-isotope ratios of blood components from captive northern fur seals (Callorhinus ursinus) and their diet: applications for studying the foraging ecology of wild otariids. Can J Fish Aq Sci 80:902-909

Lawson JW, Stenson GB (1997) Diet of northwest Atlantic harp seals (Phoca groenlandica) in offshore areas. Can J Zool 75:20952106

Le Loc'h F, Hily C (2005) Stable carbon and nitrogen isotope analysis of Nephrops norvegicus/Merluccius merluccius fishing grounds in the Bay of Biscay (Northeast Atlantic). Can J Fish Aq Sci 62:123-132

Lesage V, Hammill MO, Kovacs KM (2001) Marine mammals and the community structureof the Estuary and Gulf of St Lawrence, Canada: evidence from stable isotope analysis. Mar Ecol Progr Ser 210:203-221

Lilly GR (1987) Interactions between Atlantic cod (Gadus morhua) and capelin (Mallotus villosus) off Labrador and eastern Newfoundland: a review. Can Tech Rep Fish Aq Sci 1567: vii + 37

Livingston PA, Tjelmeland S (2000) Fisheries in boreal ecosystems. ICES J Mar Sci 57:619-627

Magnusson J, Magnusson JV (1995) Oceanic red.sh (Sebastes mentella) in the Irminger Sea and adjacent waters. Scientia Marina 59:241-254

Michener RH, Schell DM (1994) Stable isotope ratios as tracers in marine aquatic food webs. In: Lajtha K, Michener RH (eds) Stable isotopes in ecology and environmental science. Blackwell, Oxford, pp 138-157

Minagawa M, Wada E (1984) Stepwise enrichment of ${ }^{15} \mathrm{~N}$ along food chains: further evidence and the relation between ${ }^{15} \mathrm{~N}$ and animal age. Geochim Cosmochim Acta 48:1135-1140

Mitani Y, Bando T, Takai N, Sakamoto W (2006) Patterns of stable carbon and nitrogen isotopes in the baleen of common minke whale Balaenoptera acutorostrata from the western North Pacific. Fish Sci 72:69-76

Møller P (2006) Lipids and stable isotopes in marine food webs in West Greenland: trophic relations and health implications. $\mathrm{PhD}$ thesis, Natural Environment Research Institute, Denmark, p 212

Montevecchi WA (2001) Interactions between fisheries and seabirds. In: Schreiber EA, Burger J (eds) Biology of marine birds. CRC Press, Boca Raton, pp 527-557

Morato T, Solà E, Gros MP, Menezes G (2003) Diets of thornback ray (Raja clavata) and tope shark (Galeorhinus galeus) in the bottom longline fishery of the Azores, northeastern Atlantic. Fish Bull 101:590-602

Morisette L (2001) Modelisation ecosystemique du nord du golfe du Saint-Laurent Mémoire présenté à l'Université du Québec à Rimouski, p 184

Palsson OK (1985) The feeding habits of demersal fish species in Icelandic waters. Natturufroeingurinn 55:101-118

Pedersen SA, Riget F (1993) Feeding habits of redfish (Sebastes sp.) and Greenland halibut (Rheinhardtius hippoglossoides) in West Greenland waters. ICES J Mar Sci 50:445-459

Petursdottir H, Gislason A, Falk-Petersen S, Hop H, Svavarsson J (2008) Trophic interactions of the pelagic ecosystem over the Reykjanes Ridge as evaluated by fatty acid and stable isotope analyses. Deep-Sea Res II 55:83-93

Post DM (2002) Using stable isotopes to estimate trophic position: models, methods, and assumptions. Ecology 83:703-718

Robards MD, Piatt JF, Rose GA (1999) Maturation, fecundity, and intertidal spawning of Pacific sand lance in the northern Gulf of Alaska. J Fish Biol 54:1050-1068

Rodriguez-Marin E, Punzon A, Paz J, Olaso I (1994) Feeding of most abundant fish species in Flemish Cap in summer 1993. NAFO Sci Council Res Doc 94/35:33

Sarà G, De Pirro M, Romano C, Rumolo P, Sprovieri M, Mazzola A (2007) Sources of organic matter for inter-tidal consumers in Ascophyllum-shores ( $\mathrm{Sw}$ Iceland): a multi stable isotope approach. Helgol Mar Res 61:297-302

Savenkoff C, François G, Chabot D (2004) Main prey and predators of capelin (Mallotus villosus) in the northern and southern Gulf of St Lawrence during the mid-1980s and mid-1990s. Can Tech Rep Fish Aq Sci 2551:38

Sherwood GD, Rose GA (2005) Stable isotope analysis of some representative fish and invertebrates of the Newfoundland and Labrador continental shelf food web. Est Shelf Coast Sci 63:537-549

Sokal RR, Rohlf FJ (1981) Biometry. W H Freeman \& Company, New York

Sydeman WJ, Hobson KA, Pyle P, McLaren EB (1997) Trophic relationships among seabirds in central California: combined stable isotope and conventional dietary approach. Condor 99:327-336

Takai N, Yasufumi M, Yorozu A, Hoshika A (2002) Carbon source for demersal fish in the western Seto Inland Sea, Japan, examined by $\delta^{13} \mathrm{C}$ and $\delta^{15} \mathrm{~N}$ analyses. Limnol Oceanogr 47:730-741

Thompson DR, Furness RW (1995) Stable-isotope ratios of carbon and nitrogen in feathers indicate seasonal dietary shifts in northern fulmars. Auk 112:493-498

Thompson DR, Lilliendahl K, Solmundsson J, Furness RW, Waldron S, Phillips RA (1999) Trophic relationships among six species of Icelandic seabirds as determined through stable isotope analysis. Condor 101:898-903

Vesin JP, Leggett WC, Able KW (1981) Feeding ecology of capelin (Mallotus villosus) in the estuary and western Gulf of St Lawrence and its multispecies implications. Can J Fish Aq Sci 38:257-267

Yamaguchi H, Takai N, Ueno M, Hayashu I (2006) Changes of the trophic position of the Japanese flounder Paralichthys olivaceus juvenile in a sandy sublittoral area in Wakasa Bay, Sea of Japan, examined by carbon and nitrogen isotope analyses. Fish Sci $72: 449-451$ 